\title{
New Method to Calculate the Level of Consistency of the Pauli \& Kraepelin Tests
}

\author{
Sigit Haryadi; Salma Huda California \\ February 2018
}

\section{Paper DOI: 10.17605/OSF.IO/TY326}

Citation: Haryadi, S., \& California, S. H. (2018, March 14). New Method to Calculate the Level of Consistency of the Pauli \& Kraepelin Tests. Retrieved from osf.io/preprints/inarxiv/ty326

\begin{abstract}
In this paper, we proposed a modification of the measurement of the personality consistency level of the Pauli \& Kraepelin Test in the field of psychology, using the formula made in April 2016, by Sigit Haryadi, and named "the Harmony in Gradation" or "the Haryadi Index". The purpose of this proposal is because the existing formula uses only the mean value of the deviation, which leads to the possibility that the result of consistency measurement on people whose facts are different levels of consistency will be considered to have the same consistency level, on the other hand, the proposed method will be more accurate and precise in terms of providing an assessment of the level of personality consistency of a person.
\end{abstract}

\section{Calculation of Consistency Level of Human Personality on Pauli \& Kraepelin Test using "Haryadi Index"}

Emil Kraepelin was a psychiatrist of the late 19th century, who invented the psychological test kits to obtain information to diagnose human brain disorders of Alzheimer's and Dementia. Then, in 1938, Richard Pauli, Wilhelm Arnold, and Vanmethod renewed the Kraepelin test into a "check method". Then, Pauli refined, allowing the test results to be interpreted into a data about human personality. This test is now called the Pauli \& Kraepelin test and measures the Speed, Accuracy, Consistency, and Endurance when one computes a simple summation mathematical problem, then interprets it into a measure of the personality of a person undergoing a test. The time required for a Pauli test is 60 minutes with a time span of 3 minutes, so there are 20 time periods, but especially for consistency measurements, which is used only test results for 16 time periods, i.e. at the 3 rd time until the 18 th. 
This paper only proposes modifications to the measurement of consistency scores on the Pauli $\&$ Kraepelin tests, which psychologists would interpret into information about the stability of human emotions.

Without the use of complex mathematical sciences, it can be proven that existing methods contain weaknesses. For example, there are two people who have test scores over the 3rd to 18th period as follows: $A=\{5,7,5,7,5,7,5,5,7,7,5,5,5,7,7,7\}$ and $B=\{4,8,6,6,6,4$, $8,4,8,6,6,6,4,8,6,6,4,8\}$. Thus, using the existing formula, the consistency score of $\mathrm{A}$ and $\mathrm{B}$ is the same, since both have the same average deviation. In fact, instinctively A should be judged more consistent than B because B produces many values that are too small and too large compared to average values. In addition, the scores obtained by A and B using the existing method are too high.

This paper proposes a method of measurement of consistency scores on the Pauli \& Kraepelin test, using a formula made in April 2016, by Sigit Haryadi, and named as "the Haryadi Index", as an alternative to the existing method, where the use of "Haryadi Index" will preferably because in its formula it also contains "the Harmony" and "the Gradation, on the other hand, the existing formula of the Pauli \& Kraepelin Tests contains only one element, namely" the Gradation ".

In the above calculation example, due to the existing formula which only takes into account the gradations on the values of the 16 test periods, A and B by the existing method are considered to have the same consistency, whereas inter-harmony should be taken into account, as would be done by the method in this paper, the new method will give a higher consistency score of A than B.

The formula of "the Harmony in Gradation" is written as follows:

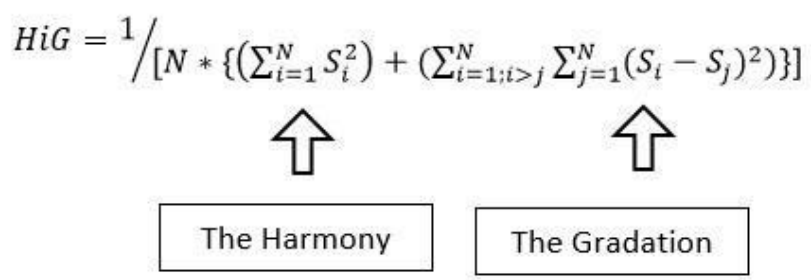

Where: HiG is "the Harmony in Gradation" of a random variable (or set) which has a sample population (or subset) $=\mathrm{N}$, and $\mathrm{Si}$ is "the Share" of each sample (or subset) $=$ comparison between strengths or the value of each sample (or subset) with the total strength of the random (or set) variable. 
Examples of the Haryadi Index or the harmony in Gradation formulas are as follows: (a) for a random variable (or set) that has two samples (or subsets): HI (2), (b) for a random variable (or set) which has three samples (or subset): HI (3), (c) for a random variable (or set) that has four samples (or subset): HI (4)

$$
\begin{aligned}
& \mathrm{HI}(2)=1 /\left[2\left\{\mathrm{~S}_{1}^{2}+\mathrm{S}_{2}{ }^{2}+\left(\mathrm{S}_{2}-\mathrm{S}_{1}\right)^{2}\right\}\right] \\
& \mathrm{HI}(3)=1 /\left[3\left\{\mathrm{~S}_{1}^{2}+\mathrm{S}_{2}{ }^{2}+\mathrm{S}_{3}{ }^{2}+\left(\mathrm{S}_{2}-\mathrm{S}_{1}\right)^{2}+\left(\mathrm{S}_{3}-\mathrm{S}_{1}\right)^{2}+\left(\mathrm{S}_{3}-\mathrm{S}_{2}\right)^{2}\right\}\right] \\
& \mathrm{HI}(4)=1 /\left[4\left\{\mathrm{~S}_{1}{ }^{2}+\mathrm{S}_{2}{ }^{2}+\mathrm{S}_{3}{ }^{2}+\mathrm{S}_{4}{ }^{2}+\left(\mathrm{S}_{2}-\mathrm{S}_{1}\right)^{2}+\left(\mathrm{S}_{3}-\mathrm{S}_{1}\right)^{2}+\left(\mathrm{S}_{4}-\mathrm{S}_{1}\right)^{2}+\left(\mathrm{S}_{3}-\mathrm{S}_{2}\right)^{2}+\left(\mathrm{S}_{4}-\mathrm{S}_{2}\right)^{2}+\left(\mathrm{S}_{4}-\mathrm{S}_{3}\right)^{2}\right\}\right]
\end{aligned}
$$

\section{Internet Calculator}

To facilitate an understanding of this method, an "internet calculator" will be created, which is a website that provides a field, where we can fill in the values of the test participants, then get the calculation results of the consistency index. But the calculator does not limit the test that has 16 sample measurements, as it did with the original Pauli \& Kraepelin test, but we are allowed to include a smaller or larger sample measurement sample of 16 . This facility is prepared to anticipate if any psychologist wishes to perform the test with a test time of less or more than one hour. And, it is guaranteed that this new method will remain accurate for any sample size.

Internet calculator that will be made there at http://sigitharyadi.net/ website and then click on the link "Consistency Test".

\section{Calculation Explanation}

a) First, calculate the share of a sample measurement $=\mathrm{Si}=$ (the value of a sample of measurement divided by the total value of all sample measurements).

b) Then, calculate the consistency index using the following formula "Haryadi Index":

$$
H I=\frac{1}{\left[N^{*}\left\{\sum_{i=1}^{N} S_{i}^{2}+\sum_{i=1}^{N} \sum_{j=1}^{N}\left(S_{i}-S_{j}\right)^{2}\right\}\right]} ; i>j
$$

c) Then determine the level of consistency as follows:

i. The index between 0.95 to 1.00 corresponds to "Very Consistent".

ii. The index between 0.75 and 0.94 corresponds with "Good consistency.

iii. The index between 0.60 to 0.74 corresponds with "Almost Less Consistent".

iv. The index between 0.50 and 0.59 corresponds to "Less Consistent.

v. The index is less than 0.50 is consistent with "Inconsistent". 


\section{Note}

In order to better understand the concept of "Harmony in Gradation" or "Haryadi Index" which became the spirit of this calculator is welcome to read the papers and books contained in the bibliography as follows

\section{References}

[1] Sigit Haryadi. (2017). Haryadi Index and Its Applications in Science of Law, Sociology, Economics, Statistics, and Telecommunications. Penerbit Elex Media Komputindo. Jakarta. ISBN: 978-602-02-9895-5.

[2] Sigit Haryadi. (2017). Indeks Haryadi dan Penerapan di Ilmu Hukum, Sosiologi, Ekonomi, Statistik, dan Telekomunikasi. Penerbit Elex Media Komputindo, Jakarta. ISBN: 978-602-02-9896-2

[3] Sigit Haryadi. (2016). Haryadi Index for Competition, Equality and Correlation Evaluation. Penerbit Lantip Safari Media, Bandung, Indonesia. ISBN: 978-60273231-3-2

[4] Sigit Haryadi. (2016). Haryadi Index untuk Evaluasi Kompetisi, Kesetaraan dan Korelasi. Penerbit Lantip Safari Media, Bandung, Indonesia. ISBN: 978-602-732313-1

[5] GarudaDivine. (2018, March 13). Paulin - Pauli \& Kraepelin Test Simulator APK. Available at https://apkpure.com/paulin-pauli-kraepelin-testsimulator/com.garudadivine.paulin

[6] HR News Ruang Informasi \& Diskusi para HR. (2018, March 13). Available at http://psikohr-news.blogspot.co.id/2013/01/pauli-test.html

[7] Haryadi, S., \& California, S. H. (2018, March 14). Metoda Baru Untuk Menghitung Tingkat Konsistensi pada Tes Pauli \& Kraepelin. Retrieved from osf.io/preprints/inarxiv/qht8j

[8] Haryadi, S. (2018, March 6). Calculation the Equity Level of an Internet Service. Retrieved from osf.io/uzcmq

[9] Haryadi, S. (2018, March 6). Perhitungan Tingkat Pemerataan Layanan Internet. Retrieved from osf.io/preprints/inarxiv/rgct3

[10] Dyah Rakhma Ariyanti; Sigit Haryadi. (October 2017). Analysis of Harmony In Gradation Index on 5G Cellular Network Quantitative Analysis. The 11th International Conference on Telecommunication Systems, Services, and Applications, At Lombok, Indonesia.

[11] Haryadi, S. (2017, November). Probabilitas Statistik Untuk Insinyur. Researchgate. DOI: 10.13140/RG.2.2.14304.58885

[12] Haryadi, S. (2018, February 1). Indeks Haryadi dan Prospeknya Untuk Menjadi Suatu "Formula of Everything (versi 31 Desember 2017). Retrieved from osf.io/zex45

[13] Haryadi, S. (2018, February 1). KALKULATOR untuk membuat Regresi Linier Tanpa Intersep. Retrieved from osf.io/emvs7

[14] Haryadi, S. (2018, February 1). Kalkulator Untuk Mengukur Tingkat Kompetisi di suatu Industri, dengan menggunakan rumus Indeks Haryadi. Retrieved from osf.io/fy $7 \mathrm{zu}$

[15] Haryadi, S. (2018, February 17). Calculation the Competition Levels between Students in Class and the Relation to the Teacher or Lecture Fairness in Teaching. Researchgate. DOI: 10.13140/RG.2.2.30359.06569 
[16] Haryadi, S. (2018, February 17). Perhitungan Tingkat Kompetisi antar Murid atau Mahasiswa di Kelas dan Kaitannya Dengan Keadilan Guru atau Dosen Dalam Mengajar. Retrieved from osf.io/a894w

[17] Haryadi, S. (2018, February 22). Equality Correlation Calculation.

Researchgate. DOI: 10.13140/RG.2.2.22068.76168

[18] Haryadi, S. (2018, February 22). Kalkulator Untuk Menghitung Korelasi Kesetaraan. Retrieved from osf.io/preprints/inarxiv/7r9jy

[19] Haryadi, S. (2018, February 24). Calculation of "Channel Cavity" on Data Communications. Equality Correlation Calculation. Research gate. DOI:

10.13140/RG.2.2.30536.01288

[20] Haryadi, S. (2018, February 24). Perhitungan "Rongga Kanal” pada Komunikasi Data. Retrieved from osf.io/preprints/inarxiv/y3wcg

[21] Haryadi, S. (2018, February 28). Ikhtisar Organisasi Regulasi Telekomunikasi. Retrieved from osf.io/preprints/inarxiv/g9m3k

[22] Haryadi, S. (2018, February 7). Statistik Terapan: Pengujian Regulasi \& Kebijakan Telekomunikasi. Retrieved from osf.io/3pkfw

[23] Haryadi, S. (2018, January 25). Chapter 1. The Concept of Telecommunication Network Performance and Quality of Service. Retrieved from osf.io/mukqb

[24] Haryadi, S. (2018, January 26). Chapter 2 of Network Performance and Quality of Service: Determination of Key Performance Indicator (KPI). Retrieved from osf.io/preprints/inarxiv/6gtnd

[25] Haryadi, S. (2018, January 26). Chapter 3 of Network Performance and Quality of Service: Technical Measurement of a Mobile Network Performance and Quality of Service. Retrieved from osf.io/q4wsz

[26] Haryadi, S. (2018, January 30). Basic Calculation of the Network's Availability and Reliability (Chapter 4 of Network Performance and Quality of Service). Retrieved from osf.io/preprints/inarxiv/z5mwq

[27] Haryadi, S. (2018, March 1). Kebijakan Lisensi Telekomunikasi. Retrieved from osf.io/7wbjf

[28] Haryadi, S. (2018, March 5). Performance Measurement of Internet Service. Retrieved from osf.io/9nsw3

[29] Haryadi, S., \& Riani, W. (2018, March 5). METODE PENETAPAN TARIF PAJAK PENGHASILAN YANG BERKEADILAN. Retrieved from osf.io/preprints/inarxiv/ayg58

[30] Nie Levin Kusuma Adiatma ; Sigit Haryadi. (2017, October). Comparison of the Haryadi Index with Existing Method in Competition, Equality, Fairness, and Correlation Level Calculation Case Study: Telecommunication Industry. The 11th International Conference on Telecommunication Systems, Services, and Applications, At Lombok, Indonesia.

[31] Sigit Haryadi. (2017). Calculation of the Mobile Communication Competition using Haryadi Index. DOI: 10.13140/RG.2.2.15634.25280

[32] Sigit Haryadi. (2017). Harmony in Gradation and its prospects as the Formula of Everything, First edition of posts: December 31, 2017. Researchgate. DOI: 10.13140/RG.2.2.19309.08169

[33] Sigit Haryadi. (2017). the Equality Correlation Method. Researchgate. DOI: 10.13140/RG.2.2.10443.80169.

[34] Sigit Haryadi. (2017). the Non-Intercept Linear Regression Method. Researchgate. DOI: 10.13140/RG.2.2.18721.71522 
[35] Sigit Haryadi. (2017). The. Fairness over Inequality Index: Unfairness is Disaster - a notebook of Sigit Haryadi. Researchgate. DOI:

10.13140/RG.2.2.34379.49449.

[36] Sigit Haryadi. (2017, December). Calculator for Measurement the

Competition Index \& Level. Researchgate. DOI: 10.13140/RG.2.2.23626.26568

[37] Sigit Haryadi. (2017, December). Calculator for non-intercept linear regression. Researchgate. DOI: 10.13140/RG.2.2.15761.94562.

[38] Sigit Haryadi. (2017, January). Calculation of the Income Equality Levels between Regions using the Haryadi Index. Researchgate. DOI: 10.13140/RG.2.2.36605.77282

[39] Sigit Haryadi. (2018, February). Applied Statistics for Assessment of the Regulation and Policy: case study in Telecommunication Industry. DOI: 10.13140/RG.2.2.15774.02884

[40] Sigit Haryadi; Dyah Rakhma Ariyanti. (October 2017). The Fairness of Resource Allocation and Its Impact on 5G Ultra-Dense Cellular Network

Performance. The 11th International Conference on Telecommunication Systems, Services, and Applications, At Lombok, Indonesia.

[41] Westi Riani; Sigit Haryadi. (2017). CALCULATOR for the Government to make the Fair Policy of Tax Rates. Researchgate. DOI:

10.13140/RG.2.2.18550.50246. Available online at http://sigitharyadi.net/multidicipline/income-tax-rates-calculator-id/

[42] Westi Riani; Sigit Haryadi. (2017). The Method Of Tax Rate Determination Based On Fairness. Prosiding Seminar Nasional SNaPP2017, Bandung, Indonesia.

[43] Haryadi, S., \& Riani, W. (2018, March 12). Telecommunication Competition and Interconnection. Retrieved from osf.io/preprints/inarxiv/7tfqd 